\title{
SILENCE AND DENIAL: Walt Whitman and the Brooklyn Bridge
}

\author{
ARTHUR GeFFEN
}

THE RECENT CENTENNIAL of the Brooklyn Bridge has occasioned a small spate of journalistic legends about Walt Whitman's reaction to what could be fairly described as the greatest technological achievement in late nineteenthcentury America. According to Hugh A. Mulligan of the Associated Press, Whitman "watched the bridge rise from his print shop on Brooklyn Heights,"1 while John J. Goldman of the Los Angeles Times has the poet exulting over the bridge as follows: "The lands welded together. The shapes arise." 2 Both of these - the biographical bit and the quotation - are spurious. Though Whitman was an apprentice printer in the 1830s, his last experience setting type was when he composed part of the 1855 Leaves of Grass in the Rome Brothers' shop, located close to but not in or on Brooklyn Heights. Moreover, during the fourteen years of the bridge's construction - from 1869 to 1883 - he did not even live in Brooklyn. He worked in Washington until his paralytic stroke in 1873 forced him to move to Camden, New Jersey, where he remained until his death in 1892, though he made a number of visits to New York in the intervening years. The words Goldman cites are Whitman's, but the quote as a whole is a pastiche of lines from two poems, "Passage to India" and "Song of the Broad-Axe," neither of which has anything to do with the bridge. ${ }^{3}$ Though one can be dismayed by Goldman and Mulligan's concoctions, one can also understand the likely impulses behind them. For a host of reasons, Whitman should have avidly followed the building of the bridge and gloried in its completion. The record, however, reveals that he was virtually silent about it, and this is a circumstance which is hard-though not impossible-to explain.

In all, Whitman made two known references to the bridge; the last occurred in 1878, five years before the completion of the bridge. ${ }^{4}$ After that date, it fails to appear in any of his poems, prefaces, essays, notebook entries, letters, or recorded conversations. What makes this absence even more mystifying is his ostensible disregard of the elaborate and nationally publicized ceremonies surrounding the opening of the bridge on 24 May 1883. However, this is but one of the many bewildering circumstances in this case.

The two short references he did make suggest the enormous potential attraction of the bridge for him. In his 1876 revision of "Song of the Exposition," confidently assuming the completion of the bridge, he places it in seventh and final position in a series of magnificent modern engineering feats which unify the world through communication and transportation: 
These triumphs of our time, the Atlantic's delicate cable,

The Pacific railroad, the Suez canal, the Mont Cenis and Gothard and Hoosac tunnels, the

Brooklyn Bridge,

This earth all spann'd with iron rails, with lines of steamships threading every sea,

Our own rondure, the current globe I bring. (11. 162-165)

Here Whitman obviously repeated some of the principal ideas he had set forth in "Passage to India" (1871), notably his fervent belief that technological progress presages even greater human and spiritual advancement. Therefore it is not surprising that the first three items in the series quoted here are the central accomplishments celebrated in the earlier poem. In 1871 he had invested the Suez Canal, Atlantic Cable, and transcontinental railroad with enormous significance; in late 1875 or early 1876 when he revised "Exposition," he apparently saw the completion of the bridge as an even more powerful event in the march of progress. ${ }^{5}$ Whitman's final mention of the bridge appears in a vivid description of New York harbor which he wrote as a newspaper article (originally published on 4 July 1878) and later incorporated into Specimen Days (1882) under the title "Manhattan from the Bay." Here he presents the harbor from the vantage point of a ship cruising through the exciting river and bay traffic: "-to the right the East river-the mast hemm'd shores - the grand obelisk-like towers of the bridge, one on either side, in haze, yet plainly defin'd, giant brothers twain, throwing free graceful interlinking loops high across the tumbled tumultuous river below" (p. 170). ${ }^{7}$ By 1878 then, the bridge had entered Whitman's visual consciousness as a striking part of what was for him almost a holy place, a location he had glorified in one of his finest early poems - "Crossing Brooklyn Ferry" (1856). Why, one wonders, should he have neglected something as poetically potent as this?

There exist numerous other compelling reasons why-under normal conditions - Whitman should not have ignored the bridge. Its history reads like a scenario which could have been scripted by the poet. ${ }^{8} \mathrm{~A}$ visionary project of immense size is brought to completion only after monumental natural and man-made difficulties, including terrible political chicanery, are surmounted. This feat is accomplished by the courageous perseverance of a dedicated leader, Washington Roebling, who is psychologically and physically devastated by the experience, by the timely emergence of an unusually strong, determined, and unladylike woman-Emily Roebling, and by the deeds and sacrifices of thousands of American laborers and mechanics. Besides Washington Roebling, there are heavy casualities, some of which border on martyrdom-John A. Roebling, who dies horribly of lockjaw initially caused by his foot's being crushed by one of Whitman's beloved Fulton ferryboats, and twenty workmen, many of whom die miserably of the bends. What an impact these events should have had on the poet who from the start 
of his career had declared himself a celebrator of heroes, martyrs, workingmen, and a new type of American woman. ${ }^{9}$

Whitman's lack of responsiveness to the Brooklyn Bridge after 1878 becomes even more mystifying when one observes how enthusiastically he responded to a comparable but arguably less striking structure. In 1880 he tells John Burroughs: "The above is a fair picture of the great Mississippi Bridge, East St Louis, where I have loafed many hours - only it sets up much higher than the print gives-I don't believe there can be a grander thing of the kind on earth."10 In Specimen Days he calls the same span "a structure of perfection and beauty unsurpassable" (p. 229). This bridge which so impressed Whitman was one whose history overlaps that of the Brooklyn Bridge. Begun in 1867, two years earlier than its eastern counterpart, it was completed under the direction of its designer-James Buchanan Eads - in 1874. Admittedly much could be said in favor of the Eads bridge: a significant aesthetic and technological achievement, it anticipated some of the most important elements of the Brooklyn Bridge. ${ }^{11}$ Nonetheless, it should hardly have been competitive with Roebling's bridge for Whitman's attention and affection, if only because St. Louis and East St. Louis - the two cities it joined-were nowhere near as significant for the poet as the two great terminuses of the other span-New York which Whitman had declared his own peerless city, ${ }^{12}$ and Brooklyn whose "ample hills" he had laid claim to in "Crossing Brooklyn Ferry." 13 As a matter of fact, Whitman had expressed an intense hope for the formal joining of these two places. In 1878, he asked: "[W]ill not the time hasten when the two shall be municipally united in one, and named Manhattan?"14 This new entity, possessing "the grandest physical habitat and surroundings of land and water the globe affords," he envisioned as the "city of superb democracy, amid superb surroundings." Whitman must have realized that the completed bridge would make this fusion not only possible but probable. Again, why did it disappear from his consciousness?

It is tempting, in trying to explain the mystery of Whitman's abandonment of the Brooklyn Bridge, to seize upon one of several simple hypotheses which spring immediately to mind. The first, based on Whitman's precarious health following his stroke in 1873 , is that throughout the last nine years of the building of the bridge-and afterward-he was too debilitated to take and register significant note of it. However, the two references cited earlier contradict this, and the time immediately surrounding the bridge's opening in May of 1883 was a relatively healthy period for the poet. On 13 April of that year he claimed to be well and commented on having had a "pretty good winter," and two days after the great celebration he reiterated that he was well. ${ }^{15}$ A second possible solution rests on Whitman's move to Camden in 1873; one might argue from this that he perhaps lost contact with New York 
and the activities going on there. This theory, however, is as faulty as the previous one. Whitman and many of the friends and family members with whom he corresponded were inveterate newspaper readers, who often shared papers, clippings, and offprints with one another, and important events in the building of the bridge were frequently reported in eastern urban papers outside of New York. Certainly the opening of the bridge, a national as well as a local event (the presence of President Chester A. Arthur testifies to this), was reported throughout the country. In addition, Whitman visited New York frequently during these years; the "Manhattan from the Bay" article was an outgrowth of one of these trips. He stayed in New York for more than three weeks in 1877, for nearly a month in 1876 , and for over two months in 1879. ${ }^{16}$ In 1881, he spent almost six weeks there on two separate visits. ${ }^{17}$ Finally, New York must have been much on his mind in 1882, since it was in that year that he composed, revised, and proofread Specimen Days, many sections of which deal with Brooklyn and New York life.

Earlier I suggested that the unification of New York and Brooklyn was for Whitman a highly foreseeable consequence of the building of the bridge. The bridge had one other predictable effect, one which may provide a key to the real reasons behind Whitman's disavowal of it. In the nineteenth century, many bridges were built with the intention of supplying a better way of crossing rivers than the old ferries, and thereby replacing them. That this was the case with the Brooktyn Bridge and the Fulton Ferry is a point powerfully made by David McCullough:

Most appealing of all for the Brooklyn people who went to New York to earn a living every day was the prospect of a safe, reliable alternative to the East River ferries. Winds, storms, tides, blizzards, ice jams, fog, none of these, they were told, would have the slightest effect on Mr. Roebling's bridge. There would be no shoving crowds at the ferryhouse loading gates. There would be no endless delays. One Christmas night a gale had caused the river to be so low the ferries ran aground and thousands of people spent the night in the Fulton Ferry house. Many winters when the river froze solid, there had been no service at all for days on end. ${ }^{18}$

Still stronger evidence that the Brooklyn Bridge was planned to supersede the Fulton (or Brooklyn) Ferry is provided by Carl W. Condit who reveals that the inclusion of a transit system on the bridge "was based on the expectation that the ferry between the two Fulton streets ... of Brooklyn and Manhattan ... would carry more than 100,000 passengers per day by the year of completion." 19 Obviously this decision was made because the almost certain capture of this ridership made the transit system economically viable.

Not only were the East River ferries (principally the Brooklyn Ferry) patently vulnerable to the superiority of the bridge, but the bridge also manifestly threatened the stability and prestige of Fulton Ferry, the flourishing area around Old Ferry Road, which led to the ferry itself, the "Gateway to Brooklyn." Since the bridge was to pass almost directly over the 
ferry slip, with its terminus several blocks higher up on Fulton Street, its completion would literally overshadow the old center of commercial and residential Brooklyn and render it obsolete. One must remember, in assessing Whitman's sensitivity to this threat to the Fulton Ferry community, that it was a place filled with strong personal associations for the poet. He had lived there as a youth, worked there as editor of the Brooklyn Eagle, and, most important of all, there published his first great work-the 1855 Leaves of Grass. ${ }^{20}$

Whitman could respond elatedly to the Eads bridge because he knew little or nothing of what it had repleced, but it was a far different story with the Brooklyn Bridge. It is impossible to overstate the psychic investment he had in ferries in general and the Fulton Ferry in particular. His most powerful articulation of these intense feelings appears in an episode of Specimen Days dated January 1882 - three and a half years after his last reference to the bridge and a little over a year before the bridge's completion:

Living in Brooklyn ... from this time [1840] forward, my life, then, and still more the following years, was curiously identified with Fulton ferry, already becoming the greatest of its sort in the world for general importance, volume, variety, rapidity, and picturesqueness. Almost daily, later, ('50 to ' 60 ,) I cross'd on the boats, often up in the pilot-houses where I could get a full sweep, absorbing shows, accompaniments, surroundings. What oceanic currents, eddies, underneath - the great tides of humanity also, with ever-shifting movements. Indeed, I have always had a passion for ferries; to me they afford inimitable, streaming, never-failing, living poems. The river and bay scenery, all about New York island, any time of a fine day - the hurrying, splashing sea-tides - the changing panorama of steamers, all sizes, often a string of big ones outward bound to distant ports - the myriads of white-sail'd schooners, sloops, skiffs, and the marvellously beautiful yachts - the majestic sound boats as they rounded the Battery and came along towards 5, afternoon, eastward bound - the prospect off towards Staten Island, or down the Narrows, or the other way up the Hudson-what refreshment of spirit such sights and experiences gave me years ago (and many a time since.) My old pilot friends, the Balsirs, Johnny Cole, Ira Smith, William White, and my young friend, Tom Gere-how well I remember them all. (p. 16)

Though this passage speaks so eloquently for itself as to require no interpretation, certain of its elements deserve to be emphasized. Despite its reminiscent tone, nothing in the past seems to have been lost. The ferry and the sights seen from it continue to delight Whitman as they formerly did; his own comrades are remembered, but they do not seem to have disappeared or died. Furthermore, the ferries are linked both to rich poetic stimulation (at once they occasion poems and are poems in themselves), and to spiritual regeneration. Whitman's propensity for hyperbole is well-known, butgiven the profound chords in his nature that the ferries touched"passion" does not seem too strong a word for him to use.

In his correspondence, Whitman gave similar vent to his enthusiasm for the ferries. Before 1873, when he was working in Washington, almost every 
return to New York occasioned a letter celebrating the renewal of his relationship with ferry life and people. In 1868 , for example, he writes that "The journey to \& fro [between Brooklyn and New York], \& especially crossing the ferry, \& resuming my acquaintance with the pilots, is quite part of my pleasure here."21 In other letters of this time, Whitman reveals the depth of his feeling for these men: "Some of the pilots are dear personal friends of mine-some, when we meet, we kiss each other (I am an exception to all their customs with others)-some of their boys have grown up since I have known them, \& they too know me \& are very friendly."22 Some of the deepest personal relationships in Whitman's life - with Peter Doyle and Harry Stafford, for example - were marked by the same blend of homoeroticism and fatherliness that emerges here. ${ }^{23}$

After 1873, though the Fulton Ferry retained its prominent position in Whitman's memory, he was able to find a pleasurable substitute for it in its counterpart on the Delaware, the ferry which ran between the foot of Market Street, Philadelphia and Federal Street, Camden, "abt. 100 rods" from 328 Mickle Street, the place in which he lived his final eight years. ${ }^{24}$ In Specimen Days, he glowingly presented this ferry and the river it plied. "Delaware River-Days and Nights," like the earlier New York pieces, glorifies the exciting profusion of river traffic, while "Scenes on Ferry and River-Last Winter's Nights" focusses on life aboard the ferry boats themselves. ${ }^{25}$ This piece contains a litany of the names of the ferrymen redolent of the homoeroticism earlier noted; singled out for special attention here is "Eugene Crosby, with his strong young arm so often supporting, circling, convoying me ... safely aboard." One of the last pieces in Specimen Days, "Only a New Ferry Boat" (dated 12 January 1882), compares a ferry boat, in this case, the Wenonah, very favorably to the finest objects of the natural world: "High up in the transparent ether gracefully balanced and circled four or five great sea hawks, while here below, amid the pomp and picturesqueness of sky and river, swam this creation of artificial beauty and motion and power, in its way no less perfect."26

Whitman's post-1873 letters reveal not an abatement but an intensification of his passion for the ferries. Multiple trips became the rule rather than the exception: "I went out at $1 / 2$ past 5 yesterday afternoon, $\&$ rode in the cars here to the ferry, \& crossed the Delaware from Camden to Philadelphia four or five times-very pleasant." 27 After the crippling stroke of 1873 , he came to regard the ferry and the river as his "greatest enjoyment." ${ }^{28}$ Later, during the 1880s, it became for him a necessity, even a form of therapy: "I don't know what I should do without the ferry, \& river, \& crossing, day \& night."29 Nearness to the ferry became essential to him; his move to the house on Mickle Street was partially dictated by this: "I moved yesterday . . . \& shall remain here for the present -it is half way nearer the ferry." ${ }^{30}$ Finally, when his infirmity became so great that he was house-ridden, it was the ferry that 
he missed most: "Alone all day \& in the room-one of the watermen came to see me yesterday afternoon \& told me all ab't the river \& ferry (of wh' I knew so much \& was fond-but now kept from a year \& more)." 31 To view this exhibition of powerful feeling properly, one must realize that if Whitman unconsciously foresaw the devastating loss of the Fulton Ferry, he must also have intuited the comparable vulnerability of the ferry to which he had shifted his old feelings. What was being built across the East River could easily be duplicated on the Delaware.

Still, one might ask why bridges could not supply Whitman with sufficient delight to allow him to accept with equanimity their replacing ferries. The answer to this lies in the fact that - Whitman's burst of enthusiasm for the Eads bridge notwithstanding-bridges for him were simply not in the same league as ferries. The superiority of the ferries in Whitman's mind goes beyond the power of his early associations; it is rooted in the contrast between crossing a bridge and crossing a ferry. In "Song of Myself," Whitman stresses the importance of his being both "in and out of the game"-being participant and observer at once. ${ }^{32}$ Clearly, a person crossing over a bridge is distanced (by mere height, if nothing else) from the life he or she sees on the river; the experience is wholly spectatorial. On the other hand, crossing on a ferry boat necessarily embroils an individual in the life of the river. Also the ferry offers greater opportunities for changing one's position on the boat to achieve a multiplicity of scenic views. On a bridge, one's primary concern becomes getting across, and one's vision becomes "tunnelled" in that direction. Ironically, John A. Roebling took this very matter into account in designing the Brooklyn Bridge's elevated promenade, a unique feature of its structure which he hoped would provide leisurely walkers with a variety of "beautiful views." 33 Whether Whitman was aware of the promenade and its function is unknown, but even if he were, the promenade could not have been totally successful for him since it was at the highest level of the bridge and therefore farthest away from the river activity. One last advantage that the ferry probably possessed over the bridge for Whitman was that it moved passengers, rather than forcing them to provide their own locomotion. Critical to Whitman's ferry experience was the sense of being propelled by a strong and constant artificial force. Writing of a crossing of the Delaware in icy winter, he stresses "the sense of power-the steady, scornful, imperious urge of our strong new engine, as she plows her way through the big and little cakes." 34 To appreciate this fully, one must remember that the paralytic stroke of 1873 deprived Whitman of his ability to walk any substantial distance and forced him to rely on artificial forms of locomotion, as well as on the physical assistance of others, including kindly ferrymen like Eugene Crosby.

For Whitman to admit the existence of the completed Brooklyn Bridge, he had to recognize the obsolescence of the ferry boat world he treasured. However, the supplantation of the ferry by the bridge also menaced him in 
his self-appointed dual role of poet and prophet. Many of his poems, especially those with a high degree of particularity, rely on the relative stability over the years of the objects of common experience presented. Nowhere is this more apparent than in "Crossing Brooklyn Ferry." Whitman concludes this poem with a paean to the specific elements of the harbor and river scene. These "dumb ministers" he glorifies principally because they provide the continuity which makes spiritual communication possible between the poet-speaker and his audience of the future: whatever he looks upon, they will also look upon. The primary object here is, of course, the ferry boat itself on which the poet and the future generations he addresses cross and will cross: "Just as you stand and lean on the rail, yet hurry with the swift current, I stood yet was hurried, / Just as you look on the numberless masts of ships and the thick-stemm'd pipes of steamboats, I look'd." ${ }^{35}$ If, however, the principal object in the poem were to become a mere relic, the entire experience could become incapable of duplication, and the deeper meanings of the work might well be lost. Thus the poem (and, by extension, much of Whitman's corpus) could be relegated to the status of a mere period piece. What Whitman probably felt to be at risk here, should he have to admit the transiency of the ferry, was nothing less than his relevance for the future-his poetic and prophetic immortality. This he could not surrender.

Throughout his adult lifetime, Whitman had publicly projected a great American future based on an almost unquestioned belief in the absolute virtue of technological advancement. Admittedly, in 1855 he did accept the supplantation of older forms by newer ones: "America . . . perceives that the corpse is slowly borne from the eating and sleeping rooms of the house ... perceives that ... it was fittest for its days ... that its action has descended to the stalwart and wellshaped heir who approaches ... and that he shall be fittest for his days." ${ }^{36}$ However, he saw this exclusively in the context of contemporary America replacing outmoded Europe. Never did he confront the extermination of older (and perhaps more valuable) American forms by newer ones, though this was surely an inescapable part of the doctrine of progress he so loudly proclaimed. So imperceptive was Whitman in this regard that Leo Marx, in his analysis of the poet's key prophetic-progressive poems, has to strain very hard to provide even the slightest hints of doubts and hesitations on Whitman's part. ${ }^{37}$ If, as seems highly likely, Whitman was unconsciously determined to ignore the price of progress and thereby preserve his vision of the glorious, technologically advanced American future in all its purity, surely the Brooklyn Bridge had to be edited out of his consciousness. And so it was.

I have tried to explain Whitman's mysterious silence after 1878 about the Brooklyn Bridge by arguing that as the bridge neared completion, it became psychologically disturbing to him because it endangered a world in which he had made deep personal investments. This threat was augmented by another 
impending danger that the retention of the bridge in his poetic consciousness would bring-acceptance of the idea that progress exacts a heavy price, that, in fact, technological advances may be no more than dubious "trade-offs." Since these feelings and ideas were subconsciously intolerable, Whitman's psyche disavowed the bridge which he otherwise probably would have accepted enthusiastically. ${ }^{38}$

Having presented this hypothesis, I would like to trace a few of the relevant historical consequences of the bridge, events which reveal some rather interesting ironies. By all accounts, the completion of the Brooklyn Bridge dealt the Fulton Ferry a mortal blow, though its demise was lingering rather than sudden. After years of failing revenues, the ferry finally succumbed in 1924. Whitman's old neighborhood was quickly and permanently blighted by the bridge. The New York City Guide described it, in 1939, as "now a small, isolated sector of musty, dilapidated buildings nestling in the shadows of the Brooklyn Bridge"-the structure whose "construction . . . destroyed its beauty" and turned it into "a slum," a "Brooklyn Bowery." 39 In 1926, the Delaware Bridge (which replaced the Brooklyn Bridge as the longest suspension bridge in the world) was opened. It affected the Camden Ferry in much the same way as the Brooklyn Bridge did the Fulton Ferry. Suffering "an immediate loss of customers," Whitman's second beloved ferry survived marginally until it was forced out of business in $1952 .{ }^{40}$ However, one bridge across the Delaware proved insufficient to handle the automobile traffic between Philadelphia and Camden, and in 1959 a new suspension toll bridge was constructed. Since the bridge built in 1926 had been renamed for Philadelphia's most illustrious citizen, Benjamin Franklin, this time Camden was given equal consideration. The new span was named the Walt Whitman Bridge. Actually, this was not the first time the poet's name was considered in this fashion. During the late '30s, there was a movement in Brooklyn to name the new plaza extending to the Brooklyn Bridge in his honor, but it failed and the distinction was given to a well-known Brooklyn clergyman and radio preacher, the Reverend Dr. Samuel Parkes Cadman. ${ }^{41}$ By a lucky turn of events, then, Whitman was saved from having his name associated in the public consciousness with the bridge his deepest private consciousness came to fear, distrust, and deny.

The University of Minnesota

\section{NOTES}

1 Minneapolis Star and Tribune, 14 August 1983, p. 3E.

2 Minneapolis Star and Tribune, 25 May 1983, p. 1A. 
3 Leaves of Grass, Comprehensive Reader's Edition, ed. Harold W. Blodgett and Sculley Bradley (New York: New York University Press, 1965), pp. 412 and 193, 11. 35 and 216; all further references to Whitman's poetry are to this edition.

4 This is noticed but not commented on by Alan Trachtenberg in Brooklyn Bridge: Fact and Symbol (Chicago: University of Chicago Press, 1979), p. $11 \mathrm{ln}$.

5 Whitman's revisions and insertions are mentioned in Sculley Bradley, Harold W. Blodgett, Arthur Golden, William White, eds., Leaves of Grass: A Textual Variorum of the Printed Poems (New York: New York University Press, 1980), 3:612, 620-621.

6 Floyd Stovall, ed., Prose Works 1892 (New York: New York University Press, 1963), 1:169-171; all further references to Specimen Days are to this edition.

7 The text quoted here is that of the New York Tribune article of 4 July 1878.

8 The details of the building of the bridge are taken from David McCullough's The Great Bridge (New York: Simon and Schuster, 1972).

9 See, in particular, Sections 18 and 33 of "Song of Myself," and "A Woman Waits for Me."

10 Edwin Haviland Miller, ed., Walt Whitman: The Correspondence (New York: New York University Press, 1964), 3:172; all further references to Whitman's letters are to this edition.

11 David Plowden, Bridges: The Spans of North America (New York: Viking Press, 1974), pp. 125-130.

12 See "First O Songs for a Prelude," p. 280, 1. 5.

13 Leaves, p. 162, 1. 57.

14 Specimen Days, p. 171 (originally published in New York Tribune, 4 July 1878).

15 Correspondence, 3:338-340.

16 See Correspondence, 3:416, n. 3.

17 Correspondence, 3:235-237, 248-251.

18 Great Bridge, p. 26.

19 The Port of New York (Chicago: University of Chicago Press, 1980), p. 243.

20 Justin Kaplan, Walt Whitman: A Life (New York: Simon and Schuster, 1980), pp. 64-73, 125-128, 198.

21 Correspondence, 2:48.

22 Correspondence, 2:88.

23 See Kaplan, p. 359.

24 Correspondence, 4:76.

25 Specimen Days, pp. 181-183, 183-188.

26 Specimen Days, p. 284.

27 Correspondence, 2:229.

28 Correspondence, 2:262. 
29 Correspondence, 5:317-318.

30 Correspondence, 3:367-368.

31 Correspondence, 4:300.

32 Leaves, p. 32, 1. 79.

33 McCullough, p. 32.

34 Specimen Days, p. 186.

35 Leaves, pp. 164-165, 11. 101-132; p. 161, 11. 25-26.

36 Leaves, p. 709.

37 The Machine in the Garden: Technology and the Pastoral Ideal in America (New York: Oxford University Press, 1970), pp. 222-225.

38 Integral to this explanation is Sigmund Freud's conception of denial, or more properly, disavowal (verleugnung). For succinct discussions of this idea, see J. LaPlanche and J.-B. Pontalis, The Language of Psycho-Analysis (New York: W. W. Norton, 1973), pp. 118-120, and The New Columbia Encyclopedia (New York: Columbia University Press, 1975), p. 745.

39 Federal Writers' Project, The New York City Guide (New York: Random House, 1939), reprinted as The WPA Guide to New York City (New York: Pantheon Books, 1982), p. 441.

40 George Wilson, Yesterday's Philadelphia (Miami, Fla.: E. A. Seamann, 1975), pp. 96, 145.

41 New York City Guide, pp. 441, 477. 